\title{
The Implicit Price of Urban Public Parks and Greenways: A Spatial-Contextual Approach*
}

\author{
Seth B. Payton** \\ Assistant Professor \\ School of Public and Environmental Affairs \\ Indiana University-Purdue University Indianapolis \\ 801 West Michigan Street \\ Indianapolis, Indiana 46202 \\ sbpayton@iupui.edu \\ John R. Ottensmann \\ Professor Emeritus \\ School of Public and Environmental Affairs \\ Indiana University-Purdue University Indianapolis
}

\begin{abstract}
:
This paper examines the value residents place on public parks in a mid-sized urban area. The analysis makes a direct contribution to the literature by examining the extent to which spatial and neighborhood context is related to the house price premium or discount associated with public recreational opportunities, natural resource areas, and urban greenways. The analysis shows that the value of public parks and greenways varies across space, neighborhood context, and park type. Community area fixedeffects are included to bolster the findings. The findings indicate that park and greenway investment should be planned and managed contextually in urban areas. Park planners can use these findings to inform public policy debates over park investment and, perhaps, support efforts focused on comprehensive neighborhood planning.
\end{abstract}

Keywords: Urban Public Parks, Urban Greenways, Spatial-Contextual Analyses, Hedonic Analysis, Property Value, Spatial Fixed-Effects

* This is an Author's Original Manuscript of an article submitted for consideration in the Journal of Environmental Planning and Management [copyright Taylor \& Francis]; Journal of Environmental Planning and Management is available online at http://www.tandfonline.com/

\section{**Corresponding Author}




\section{The Implicit Price of Urban Public Parks and Greenways: A Spatial-Contextual Approach}

\section{Introduction}

Evidence is mixed about how residents value public park and greenway proximity (Lindsey, Man, Payton, \& Dickson, 2004; McConnell \&Walls, 2005; Cho, Bowker, \& Park 2006; Anderson\& West 2006; Troy and Grove 2008). The question regarding whether or not urban public parks and greenways are assets is more complicated than practitioners and scholars initially anticipated (Crompton 2005; Troy \& Grove, 2008). Hedonic price models are a common approach for determining the revealed preference of residents for public parks and greenways. Standard hedonic models estimate the average implicit price of housing unit and neighborhood characteristics. Planners and park managers may use hedonic models to examine whether or not, and how (positively or negatively), park proximity is capitalized into housing values while holding other housing unit and neighborhood attributes constant.

In his recent review of related research, Crompton (2005) explains that most using the standard hedonic framework find that park proximity generally increases property values. A similar review of the literature by McConnell and Wallis (2005) complements Crompton’s (2005) findings. The reviews acknowledge the potential spatial and neighborhood context heterogeneity associated with those park proximity values. Specifically, the value of parks or opens space may be generally positive across most urban areas (McConnell \&Walls, 2005), but that relationship may not hold across neighborhoods within the areas studied.

The primary focus of this paper is to examine the implicit price (i.e., premium or discount) of living near public parks and greenways while taking into account the property location and neighborhood contextual factors. This study contributes to the scholarly literature by examining residents’ value of public open space (i.e., Natural Resource Areas), public 
recreational opportunities, and greenway development within a neighborhood context. First, the relationship between house values and total public park density is examined. Next, the potential variation in value residents place on those amenities is considered by location, park type, and neighborhood. Standard and contemporary hedonic methods are compared.

Public parks are a relatively static land use. ${ }^{1}$ That is, public park land is less likely to change uses in the future (Smith, Poulos, \& Kim 2002).As such, public parks become a fixture in the neighborhood. The results presented in this paper suggest that the relative value of public parks is inseparable from the context of location. These are particularly important findings as scarce resources are allocated, invested, and leveraged in an effort to create "better” urban neighborhood environments.

The remaining sections of this paper review relevant literature on valuing accessibility to public parks and greenways. Then, the conceptual framework and methods are explained. An explanation of data and results is provided next. Finally, this paper concludes with a discussion about the implications of the findings for both research and practice. This analysis is a case study of Marion County (Indianapolis), Indiana.

\section{Literature Review}

The focus on the capitalization of proximity to parks and greenways into housing values has been fairly extensive and dates back to at least 1812 (Crompton 2005). Crompton’s (2005) review of research related to the impact of parks on property values led to the conclusion that an expected 20 percent increase in the value of properties "abutting or fronting a passive park area is a reasonable starting point guideline” (p.216). McConnell and Walls (2005) provide a similar review of the literature and conclude that the examination of the implicit price of public open space should incorporate fixed effects to appropriately segment housing markets. That 
conclusion is based on varied findings across disparate community types (e.g., urban versus suburban locations) with similar data.

Beyond the notion that results may vary across types of communities, recent studies suggest that park proximity value may vary within communities. Within-community variation of the relationship between parks and house price may be attributed to the type of park or context of the neighborhood surrounding the property. For instance, some studies have found that natural park areas have a more positive property value impact than other park types (Schutlz \& King 2001; Lutzenhiser \& Netusil, 2001; Epsy and Owusu-Edusei 2001). Larger parks have been found to have greater value impacts than smaller parks (Epsy and Owusu- Edusei 2001; Tajima, 2003; Anderson and West, 2006; Cho et. al., 2010) and, in some instance, the proximity to a park may have a negative effect on housing values (Epsy and Owusu- Edusei 2001; Anderson and West, 2006; Netusil, 2005; Troy and Grove (2008); Cho, Bowker, \& Park, 2006; Cho, Clark, \& Park, 2009). Findings of negative park proximity effects have primarily been found in studies that examine the potential variation across neighborhoods.

In one of the more comprehensive analyses of neighborhood context and park values, Anderson and West (2006) construct a block group fixed effects model. They also interact distance to the nearest park with multiple neighborhood attributes separately. The Anderson and West (2006) model provides compelling, but mixed, results. The underlying assumption is that the implicit price of park proximity varies based upon separate characteristics within a block group (e.g., age of residents and income in a block group). The sparseness of park locations may contribute to the mixed results regarding how housing values are impacted as distance increases from certain types of open space. ${ }^{2}$ 
Troy and Grove (2008) examine the implicit price of park proximity by relative crime surrounding parks. Their model is operationalized by interacting distance of each observation to the nearest park and the combined robbery and rape rates of the block groups in which that park is located. The results of that study indicate that the implicit price of parks is, indeed, conditioned by crime. The associated value of parks decreases as crimes in the immediate area increases. In some instance, their estimates indicate that the influence of nearby parks housing values may be negative in higher crime neighborhoods. They do not separate their analysis by different types of parks. They also assume that crime is the only varying factor in the revealed preference for park proximity.

Two recent studies have examined the variation in park value using a geographically weighted regression (Cho, Bowker, \& Park, 2006; Cho, Clark, \& Park, 2009). Those studies focus directly on the issue of spatial heterogeneity and park proximity on housing values. Spatial heterogeneity refers to the potential variation in the direction, magnitude, and significance of parameter estimates across space (Fotheringham, Brundson, \& Charlton, 2000; 2002). Geographically weighted regression is operationalized by selecting a subset of the total observations within close spatial proximity of each observation to estimate parameters at each point across the spatial extent of the data. The contribution of those articles is that location matters. That is, one may expect different relationships between parks and house price depending on where a property is located within a given community. Geographically weighted regression models are exploratory and provide a meaningful approach for stakeholders in individual urban areas to examine the different price functions that surround specific parks in the community. Geographic weighted regression may not be adequate for general policy discussion because it does not directly illuminate the general context in which the variation in relationships exist. 


\section{Analytical Framework}

Methods for examining the capitalization of park proximity in housing values have varied. As mentioned previously, most contemporary conclusions are drawn from hedonic models. The hedonic price function assumes that a given price of a product is the result of the aggregation of several product characteristics (Lancaster, 1966). Rosen (1974) expressed that the result of the "joint-envelope” of renters and bidders is the market clearing price of each characteristic in a bundle of goods. Based on that theory, the sale price of a given property reflects the aggregation of separate components of the housing bundle. The analytic task is to estimate the implicit price for each component.

The implicit price may be estimated by hedonic models as illustrated in Equation 1. Formally, hedonic models separate the price by housing unit and neighborhood attributes. For instance, such models estimate the portion of the total price (i.e., implicit price) associated with an additional bathroom, holding other attributes constant. Other common housing unit characteristics in hedonic models include age of the structure, number of rooms, and square footage. Neighborhood, or location, characteristics may include school district achievement scores and location near public amenities, such as parks and greenway trails.

Where:

$$
\mathrm{P}=\beta_{0}+\Sigma \beta_{k} S_{k}+\Sigma \beta_{j} L_{j}+\mathrm{e}
$$

$\mathrm{P}=$ sales prices

$\mathrm{S}_{k}=$ property characteristics

$\mathrm{L}_{j}=$ neighborhood characteristics

$\beta_{0}, \beta_{k}$, and $\beta_{j}$, = corresponding parameters

$\mathrm{e}=$ random error terms 
The expectation in the standard hedonic frame work is that proximity to public parks and greenways provides a positive use value. The assumption is that all residents equally benefit from access to parks and greenways because neighborhood attributes enter the equation as independent effects. In turn, those benefits are expected to result in an equal premium (or discount) paid by residents to live near parks in all neighborhoods (McConnell \& Walls 2005).The standard approach to hedonic modeling assumes that residents value park proximity and other attributes consistent with the average property, independent of the context of the neighborhood in which those attributes are located.

Until recently, little attention was given to the neighborhood context of the capitalization of those attributes into housing values. This study takes two important components of housing price capitalization into account: space and context. Like geographically weighted regression (see Cho, Bowker, \& Park, 2006; Cho, Clark, \& Park, 2009), the spatial-contextual approach used in this analysis is an extension of Casetti’s (1972) expansion method. ${ }^{3}$ The traditional spatial expansion method examines whether estimates vary over space by interacting geographic $x$ - and $y$-coordinates with variables of the global model. The $x$ - and $y$-coordinate expansion only measures the potential estimate variation as one moves over space. Like geographically weighted regression, the traditional spatial expansion model does not consider the neighborhood context that may provide insight for general policy discussion regarding the revealed preference of park proximity (e.g., do residents value parks more in higher quality neighborhoods than in lower quality neighborhoods).

Can (1990) extends the spatial expansion approach of hedonic house price modeling by replacing geographic coordinates with a neighborhood “contextual” variable. Can’s (1990) 
adaptation of the expansion model can be utilized to examine the spatial-contextual variation of public park and greenway proximity values to inform those policy discussions.

The spatial-contextual method is formalized by beginning with an "initial model," which explicitly includes the density of park proximity as follows:

$$
\mathrm{P}=\beta_{0}+\Sigma \beta_{k} \mathrm{~S}_{k}+\Sigma \beta_{\mathrm{d}} \mathrm{DP} \mathrm{d}_{\mathrm{d}}+\mathrm{e}
$$

Where:

$$
\begin{aligned}
& \mathrm{P}=\text { sales prices } \\
& \mathrm{S}_{k}=\text { property characteristics } \\
& \mathrm{DP}_{\mathrm{d}}=\text { Density of park proximity } \\
& \beta_{0}, \beta_{k} \text {, and } \beta_{d},=\text { corresponding parameters } \\
& \mathrm{e}=\text { random error terms }
\end{aligned}
$$

The standard hedonic model is expanded to capture the "contextual” drift, where parameter $\beta_{\mathrm{k}}$ and $\beta_{\mathrm{d}}$ are allowed to vary (i.e., drift) across space. It should be noted that neighborhood characteristics (i.e., Lin Equation 1) are included in the next step as expansions.

Can (1990) operationalizes that expansion by creating a composite index of neighborhood characteristics. The Neighborhood Composite Index (referred to as Neighborhood Quality Index by Can [1990]) includes measures of neighborhood context, such as, neighborhood income (i.e., median income of block group), poverty level of a neighborhood (i.e., percentage of population below poverty line in block group), racial concentration (i.e., percent of non-white population in block group), neighborhood distress (i.e., percentage of vacant properties), and housing tenure (i.e., percentage of renters). This analysis considers the conditional relationship between house price and other attributes by expanding the initial model in the following manner:

$$
\begin{aligned}
& \beta_{\mathrm{k}}=\beta_{\mathrm{k} 0}+\beta_{\mathrm{k} 1} \mathrm{NCI} \\
& \beta_{\mathrm{d}}=\beta_{\mathrm{d} 0}+\beta_{\mathrm{d} 1} \mathrm{NCI}
\end{aligned}
$$

Where: 
Equation 4 can be used to specify $\beta_{\mathrm{k}}$ and $\beta_{\mathrm{d}}$ in Equation 2 in the following way:

$$
\mathrm{P}=\beta_{0}+\sum\left(\beta_{\mathrm{k} 0}+\beta_{\mathrm{k} 1} \mathrm{NCI}\right) \mathrm{S}_{\mathrm{k}}+\sum\left(\beta_{\mathrm{d} 0}+\beta_{\mathrm{d} 1} \mathrm{NCI}\right) \mathrm{DP}_{\mathrm{d}}+\mathrm{e}
$$

By including the expansions in Equation 4, the parameters are allowed to vary directly based on the context within which they are located. The NCI is not included as an independent variable in the expansion models. As a result, the expansion models are allowing parameters to vary across space and contexts.

The conceptual framework in this study is similar to recent studies that condition the relationship of parks and housing values by neighborhood factors (Anderson \& West, 2006; Troy \& Grove, 2008). However, this study considers the comprehensive neighborhood context rather than individual determinants. The spatial-contextual approach in this study is used to foster a general policy discussion about the complexities of revealed preferences for public parks and greenways. The empirical approach is distinct from local weighted regression techniques that address spatial heterogeneity and identify specific parks in an urban area that may be considered amenities or disamenities (Cho, Bowker, \& Park, 2006; Cho, Clark, \& Park, 2009).

While recent studies examine the distance to the nearest park or open space as a continuous measure (Anderson \& West, 2006; Troy \& Grove, 2008), the focus of this analysis is similar to studies that examine park proximity within a specified distance (Cheshire \& Shepard, 1995; Irwin \& Bockstael 2001; Geoghegan 2002). Measuring park density combines the commonly used distance and size measures in other studies rather than examining those 
relationships separately. That construct of proximity alleviates potential identity problems associated with distance to amenity measures (see Ross, Farmer, \& Lipscomb, 2011).

Park density within a 0.5 mile radius of each observation is used to examine the implicit price of park proximity for the purposes of this analysis. Specifically, park density is a measure of total park acres within a 0.5 mile radius of each observation. The 0.5 mile radius was determined empirically. Radii at $0.12,0.25,0.5$ and 0.75 miles were considered. There was not a statistically significant difference $(p<0.05)$ between park density at $0.12,0.25$, and 0.5 miles and house price in preliminary models. Under the empirically determined construct of park proximity, the distance to park is limited to accessibility that is within reasonable walking distance. Measuring park proximity by continuous distance may have led to average proximity measure as high as three miles for some park types.

\section{Data}

Data from several sources are utilized for this analysis. All modeled variables are listed and described in Table 1. The study area is Marion County (essentially, Indianapolis), Indiana. The units of analysis are properties sold in Marion County between January 2005 and September 2010. Each unit sold was merged with location characteristics through the use of a geographic information system (GIS).

\section{INSERT Table 1: Description of Variables}

The primary data source for this analysis is the Multiple Listing Service (MLS) provided by the Metropolitan Indianapolis Board of REALTORS ${ }^{\circledR}($ MIBOR). MIBOR estimates that approximately 80 percent of all properties sold in its service area during the study period are listed in the MLS database. The variables extracted from the MLS database include address, year built, sale date, number of rooms, number of bathrooms, square footage, garage type, porch type, 
cooling system, and exterior type. Lot size acreage was collected from the Marion County

Assessor's Office. The data were cleansed of obvious data entry errors and necessary missing information. The final data set for this analysis includes 46,350 arms-length transactions.

The location and general characteristics of public parks (polygon shape file) and greenway trails (polyline shape file) were provided by IndyParks (i.e. Indianapolis Department of Parks and Recreation). Park- and greenway-related characteristics considered in this analysis include location, size, and type. Specifically, park density within a 0.5 mile is considered in aggregate and by park type. Figure 1 shows the observations in the sample within a 0.5 mile radius.

\section{INSERT Figure 1: Sample Homes Sold and Proximity to Parks, Marion County}

Types of parks and recreation areas captured in the disaggregated model include regional parks, community parks, neighborhood parks, natural resource areas, and golf courses. IndyParks generally defines parks and greenways in the following way. ${ }^{4}$

- Regional parks are the largest parks in the inventory. They have some scenic, lake, or pond feature and provide cultural amenities. Preservation of open space is the goal of these areas. Eagle Creek Park is considered separately because it is much larger than any other park (4,266 acres). The average size of other regional parks is 128 acres.

- Community parks are smaller than regional parks. They provide fewer natural amenities, but the goal is to provide centers for families, nature, and smaller sports facilities. The average size of community parks is 45 acres.

- Neighborhood parks are smaller than community parks. These parks serve neighborhoods by providing playgrounds and picnic shelters. The average size of these parks is 14 acres.

- Natural Resource Areas are purposefully left undeveloped for patron enjoyment of preserved areas. The average size of natural resource areas is 26 acres.

- Public Golf Courses include non-member golf facilities.

- Greenways are multiuse trails intended to connect various neighborhoods of the city and offer increased alternative pedestrian transportation choices. The flagship greenway in Indianapolis is the Monon trail. 
Eagle Creek Park, a regional park, is considerably larger than other regional parks. Therefore, Eagle Creek Park is examined separately. Greenway variables are also included. The Monon Trail is the flagship greenway and is examined separately from other greenways. Other location characteristics include average school district standardized test scores (i.e., proxy for school quality) and a Neighborhood Composite Index (NCI). The NCI combines neighborhood characteristics that are typically considered determinants of property bid price into an index. All data to develop the index were obtained from the Bureau of the Census American Community Survey (2006-2010) at the block group level. Those characteristics include median income, percentage of non-white population, percentage of housing units that are vacant, percentage of housing units rented, and percentage of population below poverty. ${ }^{5}$

A common approach in hedonic modeling is to examine the relationship between those neighborhood characteristics and housing price independently. Including all listed neighborhood variables in one model may detrimentally affect the quality of the prediction for each attribute (e.g., multi-collinearity). While statistical properties may support the creation of the composite index, the use of a neighborhood index is primarily a substantive choice for the purposes of this analysis. The purpose of the index is to consider the spatial, contextual drift of housing price parameters. Specifically, the intent is to examine the effect of neighborhood context, comprehensively, on the implicit price of other housing components across the geography of Marion County. The focus of the analysis is particularly on public parks.

The NCI is extracted from principle component analysis (PCA). All five variables converged into one component index. Table 2 shows the factor loadings for the variables included in the PCA.

Insert Table 2: PCA Factor Loadings for the NCI 
The extracted components combined in the NCI explain 59 percent of variance in block group condition as measured by the included variables. The loadings are consistent with the expected relative correlations of neighborhood components. Increased income is expected to be positively related to price. Percentage of households below poverty, percentage of rental occupants, percentage of vacant housing units, and percentage of non-white population are expected to be inversely related to house price. Based on the factor loadings, the NCI is generally expected to be positively related to housing price.

The block group factor loadings were standardized with a mean of zero. The standardized NCI values by block group range from -2.65 to 2.40.A negative NCI score generally indicates that median income is relatively lower and the block group likely exhibits relatively higher concentrations of households below poverty, rental occupants, and non-white residents. Essentially, the standardized NCI measures the degree to which block groups are disadvantaged $(-)$ versus advantaged $(+)$. The magnitude of block group disadvantages and advantages is determined by the distance of each value from zero. The further the NCI value for a particular block group is from zero, the more the disadvantaged or advantaged the area is surrounding a given property. Figure 2 shows the spatial distribution of the NCI variable and public park and greenway locations in Marion County, Indiana.

INSERT Figure 2: NCI Distribution, Public Parks, and Greenways - Marion County

The NCI can only be used as a spatial, contextual, parametric drift variable if it is systematically distributed across space (Can 1990).An NCI that is not systematically distributed across space may only be used as a measure of the extent to which the encompassed variables are 
related to price, but not to examine the potential spatial and contextual relationship with house price. A stationary NCI variable provides a valuable control. However, a spatially systematic NCI variable reduces the magnitude of spatially-related modeling problems.

The global Moran’s I and Getis-Ord statistics were used to test the spatial interdependence of the NCI. The standardized Moran's I value is 22.52 and the standardized Getis-Ord value is 11.64.Both tests are significant at $p<0.01$, which indicates systematic and spatial clustering of the NCI. Satisfying these tests signifies that the NCI variable is useful for measuring spatial, contextual, parametric drift. The average NCI value is 0.49 for observations in the sample of sold properties.

Finally, all models include spatial fixed effects by community areas. Community area boundaries were obtained from the City of Indianapolis Department of Metropolitan Development. Figure 3 shows the 99community areas defined by the City of Indianapolis. The community fixed effects absorb across group omitted variables.

INSERT Figure 3: Neighborhoods and NCI Distribution, Marion County

\section{Results}

Table 3 shows the results of four models. Model 1 and Model 3 do not include NCI expansions. The models include estimates for park density for all park types combined and then separate models disaggregated by park type. The amount of variance in house sale price explained in the models ranges from approximately 77.7 percent to 78.6 percent.With the exception of school district standardize test scores (significant at $p<0.05$ ), all base property 
characteristics are consistently significant at $p<0.01$ with expected signs. The magnitude of those coefficients also is relatively consistent across models.

All models are semi-log (price transformed to $\ln [$ price]), so all coefficients may be multiplied by 100 and interpreted as the percentage change in price that is associated with a one unit increase in the variable of interest. More bathrooms, more total rooms, more square footage living area, more property land area, more garage bays, a porch or deck, and stone or brick exterior are positively related to house sale price. The price of homes without central air conditioning is significantly less than homes with air conditioning. Older homes sell for significantly less, ceteris paribus. Location in a school district with higher standardized test scores is significant and positively related to house price. The NCI as a standard variable in the traditional OLS model indicates that neighborhood condition significantly affects price. As expected, house prices increase as the NCI increases. With the exception of square feet living area and number of bathrooms, all expansion coefficients for the housing unit attributes are significant, indicating the price of property attributes generally vary by location and neighborhood context. The year binary variables indicate that house prices in Marion County increased between 2006 and 2005, but declined relative to 2005 between 2007 and 2010 .

\section{INSERT Table 3: Model Results}

As anticipated, the relationship between parks and house price is more complicated. Combined park density (total park density) is inversely related to house price in models that do not include the spatial-contextual expansions. Likewise, community park density, neighborhood park density, and regional parks density (excluding Eagle Creek Park) are negatively associated with price in the same model without spatial expansions (i.e., Model 3). Conversely, natural 
resource area density and golf course density are positively related to housing values when separated by park type and estimated without spatial-contextual expansions. Proximity to Eagle Creek Park, The Monon Trail, and other greenway trails is consistently significant and positively related to house prices across all models.

The spatial-contextual expansion models (Model 2 and Model 4) show the complexity of the relationships between house price and park density. Specifically, the spatial-contextual models illustrate how the capitalization of the parks into housing price varies by the characteristics of the surrounding neighborhood. The coefficients from the expansion models can be used to construct separate expansion equations to demonstrate the estimated variation of effects across neighborhoods.

Table 4summarizes the results from the spatial expansion equations for the park variables. For instance, the expansion equation for total park density draws from the coefficients in Model 2. The expanded estimation using those coefficients is:

$$
\beta_{(\text {Total Park Density })}=-0.0003+0.0004(\mathrm{NCI})
$$

The expanded equation for $\beta_{\text {(Total Park Density) indicates that the impact on the marginal prices for }}$ additional acre of park land increases as NCI increases. That is, the value associated with parks is greater in more advantaged neighborhoods, with higher NCI. The variation of $\beta_{\text {(Total Park }}$ Density)across neighborhoods may be illustrated by including different values for NCI. To demonstrate, Table 4 shows how $\beta_{\text {(Total Park Density) }}$ varies for homes from the average NCI (0.49) to one standard above (1.38) the average NCI for properties in the sample. As shown, $\beta_{\text {(Total Park }}$ Density)is negative in the average neighborhood and positive in a neighborhood for which the NCI is one standard deviation from the mean. Expanded estimates indicate that each additional acre of public park land within 0.5 miles of sample properties is associated with a 0.01 percent 
decrease in price in average NCI neighborhoods. In more advantaged neighborhoods, the estimates for the impact of total park acreage within 0.5 miles is positive. For instance, an additional acre of total public park land for a property located in a neighborhood with an NCI value that is one standard deviation from the mean NCI is associated with a marginal price increase of 0.03 percent.

\section{Table 4: Expansion Estimation}

When disaggregated by park type, the model estimates indicate that there is no statistical $(\mathrm{p}<0.05)$ spatial-contextual relationship between neighborhood park, regional parks (excluding Eagle Creek Park), or greenway trails (excluding the Monon Trail). Specifically, the model indicates that price, on average, decreases by approximately 0.14 percent and 0.04 percent for each additional neighborhood park acre and regional park acre, respectively. Greenway trails (excluding the Monon Trail) generally are associated with a 1.8 percent price increase for the average property in the average neighborhood.

The value of community parks, natural resource area, and public golf courses increases as NCI increases. An additional community park acre is associated with an estimated 0.03percent decrease at the mean sample NCI and is associated with0.02 percent increase when a property NCI is one standard deviation above the mean. Natural resource area density is positively related to price at the mean NCI. The magnitude of that positive impact is lower as neighborhoods become more advantaged. Specifically, the estimated relationship between house price and natural resource area is 0.12 percent for each additional acre at the mean NCI compared to an increase of 0.5 percent for each additional natural resource area acre when NCI is increased by one standard deviation. Finally, public golf courses are related to a 0.01 percent increase in house 
values at the mean NCI and increases to 0.05 percent with a one standard deviation increase in NCI.

Eagle Creek Park, the Monon Trail, and other greenway trails variables are binary. The estimates measure accessibility to those amenities within a 0.5 mile radius. Eagle Creek Park is associated with a 3.0 percent increase compared to a similar house located in an area with an average NCI. A property within a neighborhood that has a one standard deviation greater NCI is associated with an 8.6 percent increase in price near Eagle Creek Park. The relationship between Monon Trail accessibility and house price is significant and positive (4.1 percent), but that positive impact becomes smaller for properties as NCI increases. Other trails also are positively related to price (1.8 percent) and do not vary by NCI.

\section{Discussion}

Much of the prior research regarding the capitalization of park proximity into housing values finds a positive impact. However, recent empirical studies, parsing parks by type, has found that not all park types have equal impacts. For instance, passive parks (e.g., natural resource areas) may have different amenity values than active parks.

Much of the prior research assumes that the average effect of park proximity (no matter the type of park) on property values is invariant across an urban area and across different types of neighborhoods. In this paper, the estimated value of park proximity is allowed to vary across the neighborhood contexts. Conceptually, the intent of this paper is to examine whether or not residents of more disadvantaged neighborhoods (e.g., lower income, higher density vacant units) value nearby public parks in the same way as residents of more advantaged neighborhoods. This analysis supports the conclusion that they do not. In fact, as an aggregate measure, the models 
presented in this paper suggest an inverse relationship between total park land and house price in the average neighborhood of the sample of properties. However, that relationship becomes, or remains (but diminished), positive as one moves across the community to more advantaged neighborhoods for different park types.

Conclusions drawn from this analysis would have been misleading if the analytic framework had followed the standard hedonic approach. Generally, the conclusion would have been that proximity to park acreage, across several park types, has a negative effect on house price. Even after absorbing unobserved community effects, that negative relationship in the standard hedonic models (Model 1 and Model 3) may be due to the spatial configuration of public parks in the study area. Similarly, the average positive results found in other urban areas using the standard hedonic approach may be due to the spatial configuration of parks.

The expansion method used in this study mitigates at least some of the error associated with estimating the impact of the historical spatial pattern of urban public parks on housing values. Combining location and neighborhood factors in a spatially explicit, neighborhood contextual, framework provides more generalizable results for assessing the capitalization of park proximity into housing values. Review of similar empirical research that utilizes the standard hedonic framework in multiple study areas, shows that, on average, the impact of park proximity on house price varies among those areas. Expectedly, magnitudes of those relationships are not the same

There are at least two practical implications that can be drawn from this analysis for planners and park managers. First, consistent with the extant literature, natural resource areas (i.e., passive parks) and golf courses generally have a positive effect on house price within the context of the average neighborhood. Second, neighborhood context is an important determinant 
in the revealed preference of residents for parks and greenways. For some park types, park density is inversely related to house price in disadvantaged neighborhoods and positively related to house price in more advantaged neighborhoods. For other park types, the positive relationship between park type and house price is greater in magnitude in disadvantaged neighborhoods than in more advantaged neighborhoods.

This analysis cannot delineate the extent to which the estimated implicit price of park density is associated with park quality. However, the results do suggest that neighborhood condition and presence of park land are inextricably linked. These findings suggest a need for a more holistic approach to neighborhood revitalization and the leveraging of parks as amenities. Specifically, these results should not suggest to planners and park managers that investment in, or maintenance of, parks as a potential neighborhood asset is warranted only in more advantaged areas. On the contrary, public parks may be an appropriate leveraging mechanism for neighborhood revitalization. 


\section{References}

Anderson, S.T. \& West, S.E. (2006). Open space, residential property values, and spatial context. Regional Science and Urban Economics, 36(6), 773-789.

Can, A. (1990). The measurement of neighborhood dynamics in urban house prices. Economic Geography, 66(3).254-272.

Casetti, E. (1972). Generating models by expansion method: Applications to geographical research, Geographical Analysis, 4(1), 81-91.

Cheshire, P.C. \& Sheppard, S.C. (1995). On the price of land and the value of amenities. Economica, 62(246).247-267.

Cho, S.H., Bowker, J.M.,\& Park, W.M. (2006).Measuring the contribution of water and green space amenities to housing values: An application and comparison of spatially weighted hedonic models. Journal of Agricultural and Resource Economics, 31(3), 485-507.

Cho, S.H., Clark, W.M., \& Kim, S.G. (2009). Spatial and temporal variation in the market values of lot size and public open space. Land Economics, 85(1), 51-73.

Clapp, J.M. \& Salavei, K. (2010). Hedonic pricing with redevelopment options: A new approach to estimating depreciation effects. Journal of Urban Economics, 67(3).362-377.

Crompton, J.L. (2005). The Impact of Parks on Property Values: Empirical Evidence from tyhe Past Two Decades in the United States. Leisure Studies, 26(2), 213-234.

Dye R.F. \& McMillen, D.P. (2007). Teardowns and land values in the Chicago metropolitan area. Journal of Urban Economics, 61(1), 46-63.

Espey, M., \& Owusu-Edusei, K. (2001).Neighborhood parks and residential property values in Greenville, South Carolina. Journal of Agricultural and Applied Economics, 33(3), 487-492.

Fotheringham, A.S, Brunsdon, C., \& Charlton, M. (2002).Quantitative geography: Perspectives on spatial data analysis, Thousand Oaks, CA: Sage Publication.

Fotheringham, A.S., Brundson, C., \& Charlton, M. (2002).Geographically weighted regression: The analysis of spatially varying relationship. West Sussex, England: John Wiley \& Sons Ltd.

Geoghegan, J. (2002). The value of open space in residential land use. Land Use Policy, 19(1), 91-98.

Goeghegan, J., Lynch, L., \& Bucholtz, S. (2003). Capitalization of open spaces into housing values and the residential property tax revenue impacts of agricultural easement programs. Agricultural and Resource Economics Review, 32(1), 33-45. 
Irwin, E.G. (2002). The Effects of open space on residential property values. Land Economics, 78(4), 465-480.

Irwin, E.G. \&Bockstael, N.E. (2001).The problem of identifying land use spillovers: measuring the effects of open space on residential property values. American Journal of Agricultural Economics, 83(3), 698-704.

Jones, J.P. \& Casetti, E. (1992).Applications of the expansion method. London: Routledge.

Lanscaster, K. (1966). A new approach to consumer theory, Journal of Political Economy, 74(1), 132-157.

Lindsey, G., Man, J., Payton, S., \& Dickson, K. (2004). Property values, recreation values, and urban greenways. Journal of Park and Recreation Administration, 22 (3), 69-90.

Lutzenhizer, M. \& Netusil, N.R. (2001) The effect of opens spaces on a home's sale price. Contemporary Economic Policy, 19(3), 291-298.

McConnell, V. \& Walls, M.A. (2005).The value of open space: Evidence from studies of nonmarket benefits. Working Paper, Lincoln Institute of Land Policy, Cambridge,MA.

Netusil, N.R. (2006) Economic valuation of environmental zoning and amenities on property values: Portland, Oregon. Land Economics, 81(2), 227-246.

Rosen, S. (1974). Hedonic prices and implicit markets: Production differentiation in pure competition, Journal of Political Economy, 82(1), 34-55.

Ross, J.M., Farmer, M.C., \& Lipscomb, C.A. (2011).Inconsistency in welfare inferences from distance variables in hedonic regressions. Journal of Real Estate Finance and Economics, 43,(3), 385-400.

Schultz, S.D. \& King, D.A. (2001). The use of census data for hedonic price estimates of open space amenities and land use. Journal of Real Estate Finance and Economics, 22 (2-3), 239-252.

Smith, K.V., Poulos, C., \& Kim, H. (2002).Treating open space as an urban amenity. Resource and Energy Economics, 24(1-2),107-129.

Troy, A., Grove, J.M., (2008). Property values, parks, and crime: A hedonic analysis in Baltimore, MD. Landscape and Urban Planning. 87

\footnotetext{
${ }^{1}$ The purpose of this study is to examine the relationship between house price and public park amenities, including greenway trails and natural resource areas. The distinction here is between the likelihood of developing the land and not developing land (Irwin \& Bockstael 2001; Irwin 2002; Geoghegan, 2002; Geoghegan, Lynch, \& Bucholtz 2003).
} 
This is important for the context of this analysis because the focus is not on expected future changes or real option values (Anderson \& West 2006; Dye \& McMillen, 2007; Clapp \&Salavei, 2010). The focus is on the value associated with public parks, which have a relatively lower anticipated likelihood of being developed for other uses than private open space within the neighborhood context in which those assets are located.

${ }^{2}$ For instance, the average distance to nearest cemetery is 5,103 meters (i.e., 3.17 miles) in the Anderson and West (2006) sample.

${ }^{3}$ Expansion equations may be aspatial (Jones \&Casetti 1992). However, aspatial expansions are not intended to examine parametric drift across space.

${ }^{4}$ IndyParks manages other types of parks that consistently had no effect on house price. Monuments/memorials and mini parks were not included in the models. Nearly all monuments and memorials are located in the central business district of Indianapolis with few residential properties within 0.5 miles, which explains why exploratory analyses rendered no significant effect. Finally, mini parks are very small (averaging smaller than one-acre) plots of land that consists of cleared properties that are purchased, or acquired, on a fairly ad hoc basis by IndyParks. Those small parks consistently had no significant effect on housing values in exploratory analyses.

${ }^{5}$ Crime data are not available at the neighborhood level for the entire area studied. However, it is expected that many of the neighborhood characteristics included in the NCI are correlated with crime. 


\section{Tables}

Table 1: Description of Variables $(n=46,350)$

\begin{tabular}{|c|c|c|c|}
\hline Variable & Mean & $\begin{array}{l}\text { Standard } \\
\text { Deviation }\end{array}$ & Units/Notes \\
\hline Sale Price & $\$ 134,765.20$ & $\$ 112,800.60$ & Sale price of properties \\
\hline Total park density & 21.20 & 45.38 & Total acres of public parks within 0.5 mile \\
\hline Community park & 6.68 & 23.24 & $\begin{array}{l}\text { Total acres of community parks within } 0.5 \\
\text { mile }\end{array}$ \\
\hline Neighborhood park & 3.86 & 9.51 & $\begin{array}{l}\text { Total acres of neighborhood parks within } 0.5 \\
\text { mile }\end{array}$ \\
\hline Natural resource area & 2.38 & 12.88 & $\begin{array}{l}\text { Total acres of natural resource areas within } 0.5 \\
\text { mile }\end{array}$ \\
\hline Other regional parks & 2.08 & 14.66 & $\begin{array}{l}\text { Total acres of regional parks (except Eagle } \\
\text { Creek Park) within } 0.5 \text { mile }\end{array}$ \\
\hline Eagle Creek Park & 0.03 & 0.17 & $\begin{array}{l}\text { Value }=1 \text { if within } 0.5 \text { mile of Eagle Creek } \\
\text { Park; } 0 \text { otherwise }\end{array}$ \\
\hline Golf course & 6.17 & 31.05 & $\begin{array}{l}\text { Total acres of public golf course within } 0.5 \\
\text { mile }\end{array}$ \\
\hline Monon Trail & 0.05 & 0.22 & $\begin{array}{l}\text { Value }=1 \text { if within } 0.5 \text { mile of Monon Trail, } 0 \\
\text { otherwise }\end{array}$ \\
\hline Other trails & 0.10 & 0.30 & $\begin{array}{l}\text { Value }=1 \text { if within } 0.5 \text { of trails (with exception } \\
\text { of Monon) }\end{array}$ \\
\hline \# of bathrooms & 2.16 & 0.89 & Number of bathrooms in house \\
\hline Age & 40.34 & 29.08 & Age of house in years from sale date \\
\hline Sq. ft. living rea (x100) & 20.05 & 9.93 & Square feet of living area (X 100) \\
\hline \# of rooms & 7.32 & 2.06 & Total number of rooms in house \\
\hline Porch & 0.72 & 0.45 & Value $=1$ if porch, deck, or both; 0 otherwise \\
\hline No air conditioning & 0.10 & 0.30 & Value $=1$ if no central air; 0 otherwise \\
\hline Stone or brick facing & 0.66 & 0.48 & $\begin{array}{l}\text { Value }=1 \text { if some stone or brick exterior; } 0 \\
\text { otherwise }\end{array}$ \\
\hline \# of garage bays & 1.63 & 0.82 & Number of garage bays on property \\
\hline Lot Acreage & 0.27 & 0.38 & Acres of land on property parcel \\
\hline Neighborhood Context Index & 0.49 & 0.90 & Neighborhood Context Index \\
\hline Sold in 2005 & 0.22 & 0.42 & Year sold (omitted variable) \\
\hline Sold in 2006 & 0.21 & 0.41 & Year sold \\
\hline Sold in 2007 & 0.18 & 0.39 & Year sold \\
\hline Sold in 2008 & 0.15 & 0.35 & Year sold \\
\hline Sold in 2009 & 0.13 & 0.34 & Year sold \\
\hline Sold in 2010 & 0.10 & 0.30 & Year sold \\
\hline SAT score & 948.66 & 66.69 & Mean Standardized test score in school district \\
\hline
\end{tabular}


Table 2: PCA Factor Loadings for the NCI

\begin{tabular}{|c|c|}
\hline PCA Variables & Factor Loadings* \\
\hline Median income & 0.849 \\
\hline Percentage households below poverty & -0.826 \\
\hline Percentage rental occupants & -0.801 \\
\hline Percentage vacant housing units & -0.696 \\
\hline Percentage of population non-white & -0.613 \\
\hline
\end{tabular}

Table 3: Model Results ( $\mathrm{n}=46,350)$

\begin{tabular}{|c|c|c|c|c|}
\hline \multirow[b]{2}{*}{ VARIABLES } & \multicolumn{2}{|c|}{ Combined All Parks } & \multicolumn{2}{|c|}{ By Park Type } \\
\hline & $\begin{array}{c}\text { w/oSpatial } \\
\text { Expansion } \\
\text { (1) }\end{array}$ & $\begin{array}{l}\text { w/ Spatial } \\
\text { Expansion } \\
\text { (2) }\end{array}$ & $\begin{array}{c}\text { w/o Spatial } \\
\text { Expansion } \\
\text { (3) }\end{array}$ & $\begin{array}{c}\text { w/ Spatial } \\
\text { Expansion } \\
\text { (4) }\end{array}$ \\
\hline Total Park Density & $\begin{array}{c}-0.0001^{* * *} \\
(0.0000)\end{array}$ & $\begin{array}{c}-0.0003^{* * *} \\
(0.0001)\end{array}$ & & \\
\hline Total Park Density *NCI & & $\begin{array}{c}0.0004 * * * \\
(0.0000)\end{array}$ & & \\
\hline Community Park & & & $\begin{array}{c}-0.0004 * * * \\
(0.0001)\end{array}$ & $\begin{array}{c}-0.0005^{* * *} \\
(0.0001)\end{array}$ \\
\hline Community Park *NCI & & & & $\begin{array}{c}0.0005^{* * *} \\
(0.0001)\end{array}$ \\
\hline Neighborhood Park & & & $\begin{array}{c}-0.0019 * * * \\
(0.0002)\end{array}$ & $\begin{array}{c}-0.0014 * * * \\
(0.0002)\end{array}$ \\
\hline Neighborhood Park*NCI & & & & $\begin{array}{l}-0.0001 \\
(0.0002)\end{array}$ \\
\hline Nat. Resource Area & & & $\begin{array}{c}0.0005^{* * *} \\
(0.0001)\end{array}$ & $\begin{array}{c}0.0015^{* * *} \\
(0.0003)\end{array}$ \\
\hline Nat. Resource Area*NCI & & & & $\begin{array}{c}-0.0007 * * * \\
(0.0002)\end{array}$ \\
\hline Other Regional Parks & & & $\begin{array}{l}-0.0003 * \\
(0.0002)\end{array}$ & $\begin{array}{c}-0.0004 * * \\
(0.0002)\end{array}$ \\
\hline Other Regional Parks*NCI & & & & $\begin{array}{c}0.0003 \\
(0.0002)\end{array}$ \\
\hline Eagle Creek Park & & & $\begin{array}{l}0.0233 * \\
(0.0134)\end{array}$ & $\begin{array}{l}0.0027 \\
(0.0162)\end{array}$ \\
\hline
\end{tabular}




\begin{tabular}{|c|c|c|c|c|}
\hline Eagle Creek Park*NCI & & & & $\begin{array}{c}0.0621 * * * \\
(0.0147)\end{array}$ \\
\hline Golf Course & & & $\begin{array}{l}0.0001 * \\
(0.0001)\end{array}$ & $\begin{array}{l}-0.0001 \\
(0.0001)\end{array}$ \\
\hline Golf Course*NCI & & & & $\begin{array}{c}0.0004 * * * \\
(0.0001)\end{array}$ \\
\hline Monon Trail & $\begin{array}{c}0.0535 * * * \\
(0.0115)\end{array}$ & $\begin{array}{c}0.0563 * * * \\
(0.0123)\end{array}$ & $\begin{array}{c}0.0428 * * * \\
(0.0116)\end{array}$ & $\begin{array}{c}0.0417 * * * \\
(0.0125)\end{array}$ \\
\hline Monon Trail*NCI & & $\begin{array}{c}-0.0266 * * \\
(0.0106)\end{array}$ & & $\begin{array}{c}-0.0247 * * \\
(0.0106)\end{array}$ \\
\hline Other Trails & $\begin{array}{c}0.0211^{* * *} \\
(0.0073)\end{array}$ & $\begin{array}{c}0.0245^{* * *} \\
(0.0072)\end{array}$ & $\begin{array}{l}0.0181^{* *} \\
(0.0073)\end{array}$ & $\begin{array}{c}0.0182 * * \\
(0.0073)\end{array}$ \\
\hline Other Trails*NCI & & $\begin{array}{c}0.0066 \\
(0.0066)\end{array}$ & & $\begin{array}{c}0.0102 \\
(0.0067)\end{array}$ \\
\hline \# of Bathrooms & $\begin{array}{c}0.0806 * * * \\
(0.0033)\end{array}$ & $\begin{array}{c}0.0837 * * * \\
(0.0036)\end{array}$ & $\begin{array}{c}0.0799 * * * \\
(0.0033)\end{array}$ & $\begin{array}{c}0.0833 * * * \\
(0.0036)\end{array}$ \\
\hline \# of Bathrooms*NCI & & $\begin{array}{l}-0.0001 \\
(0.0032)\end{array}$ & & $\begin{array}{l}-0.0012 \\
(0.0032)\end{array}$ \\
\hline Age & $\begin{array}{c}-0.0036 * * * \\
(0.0001)\end{array}$ & $\begin{array}{c}-0.0037^{* * *} \\
(0.0001)\end{array}$ & $\begin{array}{c}-0.0035 * * * \\
(0.0001)\end{array}$ & $\begin{array}{c}-0.0036^{* * *} \\
(0.0001)\end{array}$ \\
\hline Age*NCI & & $\begin{array}{c}0.0000 * * * \\
(0.0000)\end{array}$ & & $\begin{array}{c}0.0000 * * * \\
(0.0000)\end{array}$ \\
\hline sqft100 & $\begin{array}{c}0.0160 * * * \\
(0.0003)\end{array}$ & $\begin{array}{c}0.0170^{* * *} \\
(0.0004)\end{array}$ & $\begin{array}{c}0.0160^{* * *} \\
(0.0003)\end{array}$ & $\begin{array}{c}0.0169 * * * \\
(0.0004)\end{array}$ \\
\hline Sq.Ft. Living Area(x100)*NCI & & $\begin{array}{l}-0.0000 \\
(0.0000)\end{array}$ & & $\begin{array}{l}-0.0000 \\
(0.0000)\end{array}$ \\
\hline \# of Rooms & $\begin{array}{c}0.0341 * * * \\
(0.0013)\end{array}$ & $\begin{array}{c}0.0329 * * * \\
(0.0015)\end{array}$ & $\begin{array}{c}0.0346^{* * *} \\
(0.0013)\end{array}$ & $\begin{array}{c}0.0332 * * * \\
(0.0015)\end{array}$ \\
\hline \# of Rooms*NCI & & $\begin{array}{c}0.0045^{* * *} \\
(0.0012)\end{array}$ & & $\begin{array}{c}0.0044 * * * \\
(0.0012)\end{array}$ \\
\hline Porch & $\begin{array}{c}0.1144 * * * \\
(0.0039)\end{array}$ & $\begin{array}{c}0.1247 * * * \\
(0.0041)\end{array}$ & $\begin{array}{c}0.1143^{* * *} \\
(0.0039)\end{array}$ & $\begin{array}{c}0.1249 * * * \\
(0.0041)\end{array}$ \\
\hline Porch*NCI & & $\begin{array}{c}-0.0305^{* * *} \\
(0.0041)\end{array}$ & & $\begin{array}{c}-0.0313^{* * *} \\
(0.0041)\end{array}$ \\
\hline No Air Conditioning & $\begin{array}{c}-0.5442 * * * \\
(0.0065)\end{array}$ & $\begin{array}{c}-0.4853^{* * *} \\
(0.0065)\end{array}$ & $\begin{array}{c}-0.5438 * * * \\
(0.0065)\end{array}$ & $\begin{array}{c}-0.4851^{* * * *} \\
(0.0065)\end{array}$ \\
\hline No Air Conditioning*NCI & & $\begin{array}{c}0.2067 * * * \\
(0.0070)\end{array}$ & & $\begin{array}{c}0.2053 * * * \\
(0.0070)\end{array}$ \\
\hline Stone or Brick Facing & $\begin{array}{c}0.0825 * * * \\
(0.0042)\end{array}$ & $\begin{array}{c}0.0805^{* * *} \\
(0.0044)\end{array}$ & $\begin{array}{c}0.0824 * * * \\
(0.0042)\end{array}$ & $\begin{array}{c}0.0808 * * * \\
(0.0044)\end{array}$ \\
\hline Stone or Brick Facing*NCI & & $0.0191 * * *$ & & $0.0193 * * *$ \\
\hline
\end{tabular}




\begin{tabular}{|c|c|c|c|c|}
\hline \# of Garage Bays & $\begin{array}{l}0.1105^{* * *} \\
(0.0026)\end{array}$ & $\begin{array}{c}0.1052 * * * \\
(0.0027)\end{array}$ & $\begin{array}{c}0.1101^{* * *} \\
(0.0026)\end{array}$ & $\begin{array}{c}0.1051^{* * *} \\
(0.0027)\end{array}$ \\
\hline \# of Garage Bays*NCI & & $\begin{array}{l}0.0060 * * \\
(0.0027)\end{array}$ & & $\begin{array}{l}0.0060 * * \\
(0.0027)\end{array}$ \\
\hline Lot Acreage & $\begin{array}{c}0.1217 * * * \\
(0.0050)\end{array}$ & $\begin{array}{c}0.1590 * * * \\
(0.0076)\end{array}$ & $\begin{array}{c}0.1205^{* * *} \\
(0.0050)\end{array}$ & $\begin{array}{c}0.1563 * * * \\
(0.0076)\end{array}$ \\
\hline Lot Acreage*NCI & & $\begin{array}{c}-0.0583 * * * \\
(0.0059)\end{array}$ & & $\begin{array}{c}-0.0576 * * * \\
(0.0059)\end{array}$ \\
\hline $\begin{array}{l}\text { Neighborhood Context } \\
\text { Index(NCI) }\end{array}$ & $\begin{array}{c}0.1234^{* * *} \\
(0.0030)\end{array}$ & & $\begin{array}{c}0.1209 * * * \\
(0.0030)\end{array}$ & \\
\hline Sold in 2006 & $\begin{array}{c}0.0211^{* * *} \\
(0.0051)\end{array}$ & $\begin{array}{c}0.0207^{* * *} \\
(0.0051)\end{array}$ & $\begin{array}{c}0.0199 * * * \\
(0.0050)\end{array}$ & $\begin{array}{c}0.0195^{* * *} \\
(0.0050)\end{array}$ \\
\hline Sold in 2007 & $\begin{array}{c}-0.0370 * * * \\
(0.0053)\end{array}$ & $\begin{array}{c}-0.0373 * * * \\
(0.0053)\end{array}$ & $\begin{array}{c}-0.0374 * * * \\
(0.0052)\end{array}$ & $\begin{array}{c}-0.0374 * * * \\
(0.0052)\end{array}$ \\
\hline Sold in 2008 & $\begin{array}{c}-0.1484 * * * \\
(0.0057)\end{array}$ & $\begin{array}{c}-0.1490 * * * \\
(0.0057)\end{array}$ & $\begin{array}{c}-0.1478 * * * \\
(0.0056)\end{array}$ & $\begin{array}{c}-0.1483 * * * \\
(0.0056)\end{array}$ \\
\hline Sold in 2009 & $\begin{array}{c}-0.1738 * * * \\
(0.0059)\end{array}$ & $\begin{array}{c}-0.1746 * * * \\
(0.0058)\end{array}$ & $\begin{array}{c}-0.1715^{* * *} \\
(0.0057)\end{array}$ & $\begin{array}{c}-0.1725^{* * *} \\
(0.0057)\end{array}$ \\
\hline Sold in 2010 & $\begin{array}{c}-0.2382 * * * \\
(0.0065)\end{array}$ & $\begin{array}{c}-0.2387 * * * \\
(0.0065)\end{array}$ & $\begin{array}{c}-0.2376^{* * *} \\
(0.0063)\end{array}$ & $\begin{array}{c}-0.2379 * * * \\
(0.0063)\end{array}$ \\
\hline SAT Score & $\begin{array}{c}0.0002 * * \\
(0.0001)\end{array}$ & $\begin{array}{l}0.0002^{* *} \\
(0.0001)\end{array}$ & $\begin{array}{l}0.0001^{* *} \\
(0.0001)\end{array}$ & $\begin{array}{c}0.0002^{* * *} \\
(0.0001)\end{array}$ \\
\hline Constant & $\begin{array}{c}10.5133^{* * *} \\
(0.0624)\end{array}$ & $\begin{array}{c}10.5521^{* * *} \\
(0.0616)\end{array}$ & $\begin{array}{c}10.5447 * * * \\
(0.0627)\end{array}$ & $\begin{array}{c}10.5227^{* * *} \\
(0.0624)\end{array}$ \\
\hline Observations & 46,350 & 46,350 & 46,350 & 46,350 \\
\hline R-squared & 0.777 & 0.785 & 0.778 & 0.786 \\
\hline Adj R-squared & 0.776 & 0.785 & 0.777 & 0.785 \\
\hline
\end{tabular}

All models include community area fixed effects (significant at $\mathrm{p}<0.001$ )

Standard errors in parentheses

*** $\mathrm{p}<0.01, * * \mathrm{p}<0.05, * \mathrm{p}<0.10$ 
Table 4: Expansion Estimation

\begin{tabular}{|c|c|c|}
\hline Expansion Equation & $\begin{array}{c}\beta \text { At NCI mean } \\
(0.49)\end{array}$ & $\begin{array}{l}\text { BIncreasing NCI } \\
\text { one st.dev. (1.39) }\end{array}$ \\
\hline \multicolumn{3}{|c|}{$\begin{array}{c}\text { Spatial-Contextual Model w/ Neighborhood Fixed Effects (Model 2): } \\
\text { Density All Parks }\end{array}$} \\
\hline$\beta($ Total Park Density) $=-0.0003+0.0004(\mathrm{NCI})$ & -0.0001 & 0.0003 \\
\hline \multicolumn{3}{|c|}{$\begin{array}{l}\text { Spatial-Contextual Model w/ Neighborhood Fixed Effects (Model 4): } \\
\text { Density by Park Type }\end{array}$} \\
\hline$\beta($ Community Park $)=-0.0005+0.0005(\mathrm{NCI})$ & -0.0003 & 0.0002 \\
\hline$\beta($ Neighborhood Park $)=-0.0014-0.0001(\mathrm{NCI})$ & -0.0014 & -0.0014 \\
\hline$\beta($ Nat. Resource Area) $=0.0015-0.0007(\mathrm{NCI})$ & 0.0012 & 0.0005 \\
\hline$\beta($ Other Regional Parks) $=-0.0004+0.0003(\mathrm{NCI})$ & -0.0004 & -0.0004 \\
\hline$\beta($ Public Golf Course $)=-0.0001+0.0004($ NCI $)$ & 0.0001 & 0.0005 \\
\hline \multicolumn{3}{|c|}{$\begin{array}{c}\text { Spatial-Contextual Model w/ Neighborhood Fixed Effects (Model 4): } \\
\text { Binary Park and Greenway Variables }\end{array}$} \\
\hline$\beta($ Eagle Creek Park) $=0.0027+0.0621(\mathrm{NCI})$ & 0.0304 & 0.0863 \\
\hline$\beta($ Monon Trail $)=0.0417+-0.0247(\mathrm{NCI})$ & 0.0296 & 0.0074 \\
\hline$\beta($ Other Greenway Trails) $=0.0182+0.0102(\mathrm{NCI})$ & 0.0182 & 0.0182 \\
\hline
\end{tabular}




\section{Figures}

Figure 1: Sample Homes Sold and Proximity to Parks, Marion County

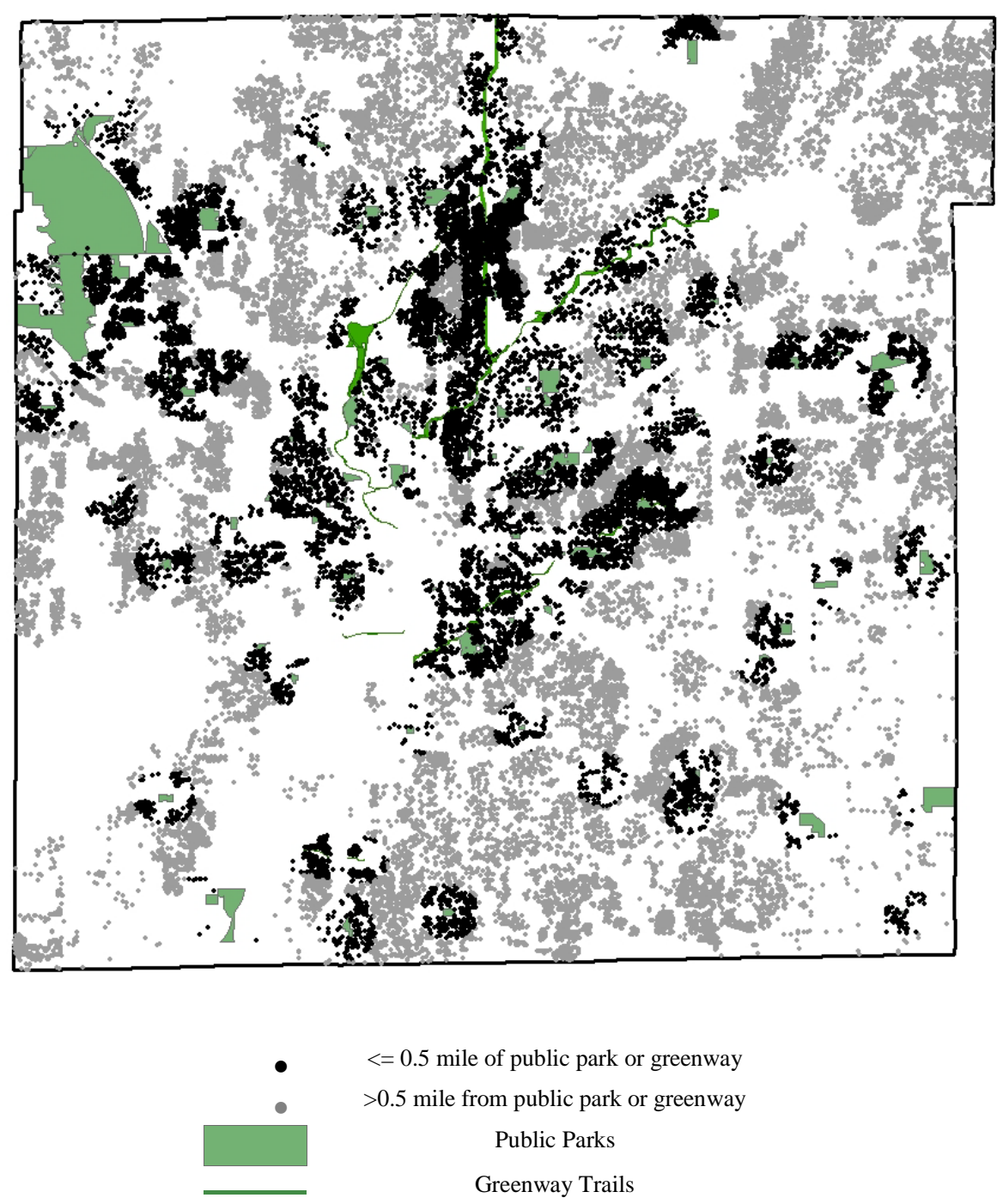


Figure 2: NCI Distribution, Public Parks, and Greenways - Marion County

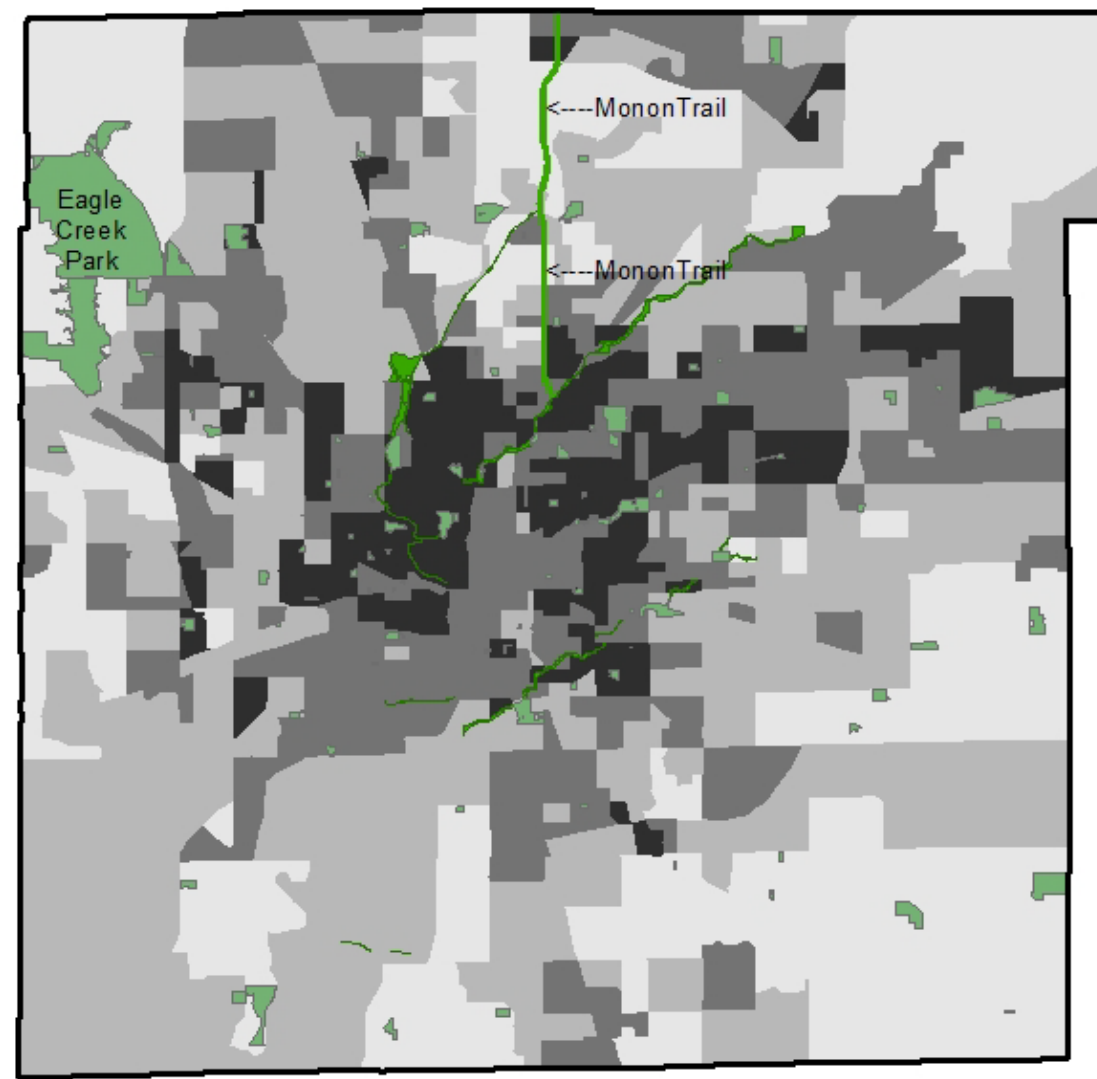

NCI by Block Group

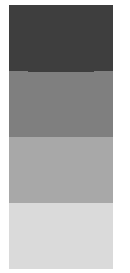

Less than -1.00

-0.99 to 0.00

0.01 to 1.00

Greater than 1.00

Public Parks

Greenway Trails 
Figure 3: Community Areas and NCI Distribution, Marion County

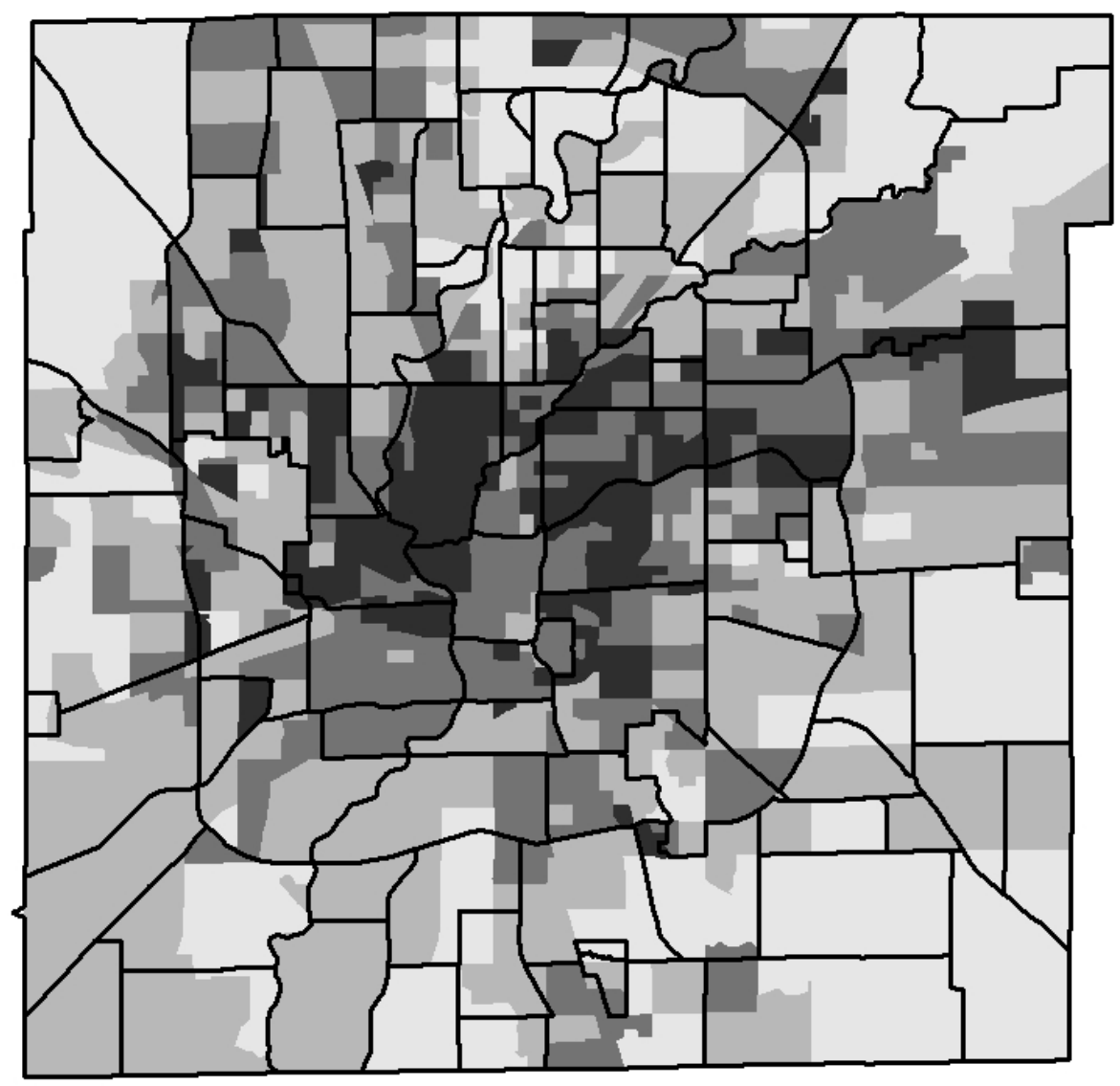

NCI by Block Group

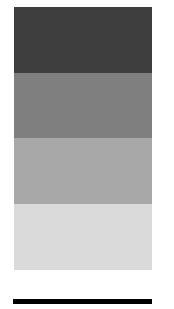

Less than -1.00

-0.99 to 0.00

0.01 to 1.00

Greater than 1.00

Neighborhoods 